The Year 2000 International Research

Conference on Sodial Seaurity

Helsinki, 25-27 September 2000

"Social security in the global village"

\title{
Migration and social security: \\ Parochialism in the global village
}

Simon ROBERTS

Research Associate

Centre for Research in Social Policy

Department of Social Sciences

Loughborough University

United Kingdom

INTERNATIONAL SOCIAL SECURITY ASSOCIATION (ISSA) RESEARCH PROGRAMME 


\title{
Migration and social security: Parochialism in the global village
}

\section{Paper presented at \\ The Year 2000 International Research Conference on Social Security Helsinki, 25-27 September 2000}

'Social security in the global village'

\author{
Dr Simon Roberts \\ Research Associate \\ Centre for Research in Social Policy \\ Department of Social Sciences \\ Loughborough University \\ Loughborough, Leicestershire, LE11 3TU \\ England
}

Direct Line: $+44(0) 1509223876$

Fax: (0)1509 213409

Email: S.Roberts@lboro.ac.uk

\begin{abstract}
The increasingly global characteristic of migration has considerable implications for social security.

This paper looks at both the direct effect of immigration status on benefit eligibility, and the effect of benefit entitlement conditions themselves on third country nationals in the fifteen member countries of the European Union (EU) at different stages of settlement. It analyses each country's benefit entitlement conditions by nationality criteria, contribution requirements and stipulations about years of residence, and the requirement to be present in the country.

The paper draws attention to the important distinction between contributory and noncontributory benefits, with the latter tending to be less open to migrants and less likely to be included in international agreements; the lack of agreements between EU member countries and some sending countries with large stocks and flows; and suggests that the social security arrangements in the EU member countries create a hierarchy of statuses for migrants which may exclude those migrants who are most in need.
\end{abstract}

Finally the paper examines the European Commission's proposal to extend Regulation (EEC) 1408/71 to include third country nationals and concludes that the proposal moves beyond the principle of reciprocity towards a more inclusive conception of European citizenship. 


\section{Introduction}

The increasingly global characteristic of migration has considerable implications for social security.

This paper looks at both the direct effect of immigration status on benefit eligibility, and the effect of benefit entitlement conditions themselves on third country nationals in the fifteen member countries of the European Union (EU) at different stages of settlement. It analyses each country's benefit entitlement conditions by nationality criteria, contribution requirements and stipulations about years of residence, and the requirement to be present in the country. It then examines the extent to which international social security agreements, including EU regulations, mitigate exclusion from benefit entitlement.

The paper draws attention to the important distinction between contributory and noncontributory benefits, with the latter tending to be less open to migrants and less likely to be included in international agreements; the lack of agreements between EU member countries and some sending countries with large stocks and flows; and suggests that the social security arrangements in the EU member countries create a hierarchy of statuses for migrants which may exclude those migrants who are most in need.

Finally the paper examines the European Commission's proposal to extend Regulation (EEC) 1408/71 to include third country nationals and concludes that the proposal moves beyond the principle of reciprocity towards a more inclusive conception of European citizenship.

\section{$2 \quad$ Migration}

People migrate for many reasons: to escape war, famine or persecution, to find better land or a better climate, or to find work or work that is better paid. The common theme is that migrants want to improve their quality of life. Some migrants travel great distances, sometimes from one side of the world to the other; others move a few dozen miles from the countryside to the city or from a declining region to a developing one.

Migration is not, of course, a recent phenomenon. The complex distribution of ethnic and linguistic groupings across Western Europe testifies to the multitude of waves of migration that has layered the European landscape since the early Iron Age (Rokkan and Unwin, 1983).

Industrial Europe has long experienced the ebb and flow of both economically and politically motivated migration. During the nineteenth and early twentieth centuries Europe was a net exporter of people. Between 1820 and 1940 an estimated 55-60 million people left Europe for overseas (King, 1990).

After the Second World War, and in particular during the 1950s, 1960s and early 1970s, there was large-scale migration from the European periphery, Mediterranean basin and former colonies into industrial North West Europe. This was motivated by the coincidence 
of people's desire to find better-paid work with the requirements of the industrial economies of North West Europe for cheap unskilled labour (Thomas, 1982; Clout et al., 1985; King, 1990, 1993; Castles and Miller, 1993).

What is significant about 'modern' migration is that the barriers that must be crossed are not the rivers and mountains that confronted Rokkan and Unwin's early Iron Age men and women, but national frontiers.

\section{$3 \quad$ Sources of Migrants' Rights}

The study identified five sources of social security rights for migrants from outside the EU. These are:

1) The domestic arrangements of the member states;

2) The plethora of bilateral agreements entered into separately by the member states;

3) EU Regulations ;

4) The various association and co-operation agreements entered into by the EU and the member states in partnership; and

5) Council of Europe instruments.

\section{The Domestic Arrangements of the Member States}

\subsection{Direct Effects of Immigration Policies}

The member countries of the EU differ in the social security arrangements they make for third country nationals (Roberts and Bolderson, unpublished, 1993; von Maydell and Schulte, 1995; Bolderson and Roberts, 1997; Yorens, 1997; Roberts, 1998a; Roberts and Bolderson, 1999). Some of the countries discriminate directly against third country nationals in that immigration status disallows a claim to benefit or a claim jeopardises the right to remain in the country. For example, entitlement to social assistance in Denmark for more than a temporary period is reserved for people who have lived in Denmark for the previous three years. Social assistance for people who have lived in Denmark for a shorter period of time is decided by local authorities acting under guidance laid down by the Ministry of Social Affairs. If a claim for social assistance is made by a person who has lived in Denmark for less than three years, s/he may be deported.

In France a Special Residence Card is only granted if the applicant can demonstrate that s/he has sufficient funds to support her or himself. Similarly in Italy the first extension of the residence card is dependant on the applicant having sufficient funds. In Luxembourg and Portugal all foreigners must prove their means of subsistence in order to have their residence permit extended.

Immigration policies also restrict access to benefits for spouses. A claim by the relative to social assistance before a long-term permit is granted may jeopardise his or her right to remain in each of the countries. For example, spouses may not claim social assistance in Austria until they have worked in a particular country for five years, when they may become entitled to a Permanent Residence Permit. However, satisfying this condition in Austria is 
difficult as residence and work permits are issued separately with a quota for each and it may be very difficult for a spouse to get a work permit and accrue sufficient contributions to gain entitlement to benefits. In Belgium, Finland, the Netherlands, Sweden and the UK a claim for social assistance within the first year of arrival may result in the person being refused continuing leave to stay. In France a spouse who claims within the first three months of arrival may be expelled. In Portugal even a long-term residence permit granted to a spouse can be withdrawn if the family cannot provide proof of their means of subsistence.

\subsection{Effect of Benefit Entitlement Conditions}

\section{Nationality}

In other cases the benefit entitlement conditions themselves discriminate directly against third country nationals in that they reserve entitlement for the nationals of the receiving country only. Although non of the fifteen EU member countries reserve contributory benefits for nationals only, almost half require that somebody be a national of their country in order to claim at least some of their non-contributory benefits. Austria, Belgium, Denmark, France, Greece, Italy and Portugal all have nationality conditions attached to some of these benefits (Bolderson and Roberts, 1997; Roberts, 1998a; Roberts and Bolderson, 1999).

In Belgium the main social assistance benefit, the Minimex, and the two non-contributory means-tested categorical benefits, the Guaranteed Income for Older People and the Disability Allowance, are confined to Belgian nationals. In France eight benefits are restricted to nationals (Allowance for Elderly Employed Persons, Allowance for Elderly Self-Employed Persons, Special Old Age Allowance, Supplementary Allowance of the National Fund of Solidarity, Income Support for Spouses of Salaried or Non-Salaried Workers, Allowance for Handicapped Adults, Mothers' Allowance and Solidarity Allowance). Greece has an assortment of categorical means-tested benefits, all of which, with the exception of those designed for children and expectant women, are confined to Greek nationals. Italy restricts three of its benefits (Social Pension, Allowance for the Handicapped and Attendance Allowance) to nationals only. All categorical means-tested non-contributory benefits in Portugal, that is, Family Allowance, Supplementary Allowance for Disabled Children and Young People, Nursing allowance, Orphan's Pension, Survivors' Grants and Social Invalidity Pension, are reserved for Portuguese nationals.

As each of these countries is a signatory of the Geneva Convention, the above benefits are open to those people who have been granted refugee status. However, Portugal requires six months' residence for refugees in order to be entitled to its non-contributory means-tested benefits listed above.

Although there is no discrimination by nationality with respect to contributory benefits claimed domestically, there is, however, discrimination by nationality with regard to contributory benefits when it comes to exporting them (Bolderson and Gains, 1993). Some countries do not allow non-nationals to claim some of their benefits from abroad. This is the case with France for example, where pensions cannot be claimed from abroad by nonnationals; and Sweden, where flat-rate pensions are payable abroad for Swedish nationals 
entitled to income-related supplementary pensions based on previous gainful occupation in Sweden, but not for non-nationals. Other countries pay higher amounts to their own nationals who are living abroad. Germany credits nationals who are going abroad with extra premiums to which non-nationals are not entitled. The Finnish contributory old age pension, survivor's pension and invalidity pension can be retained and claimed abroad by Finnish nationals. Foreign nationals need the consent of the Central Pension Security Agency if they wish to have one of these pensions paid abroad.

\section{Residence}

In many cases the benefit entitlement conditions discriminate indirectly against third country nationals in that they require the satisfaction of a lengthy past period of residence or the satisfaction of criteria that may be more difficult for a migrant to satisfy than it is for a national of the receiving country.

Although there are no residence conditions attached to contributory benefits, many of the countries attach residence conditions to tax-financed benefits. It is possible to identify different types of residence conditions. For analytical reasons these are distinguished into: ordinary and social residence; prior residence; and presence (Bolderson and Roberts, 1997).

\section{Ordinary and Social Residence}

In the UK, receipt of Income Support, Income-Based Job Seekers Allowance, Council Tax Benefit and Housing Benefit are restricted to those who are 'habitually resident'. This term is not defined in the legislation but determined with reference to subjective criteria to do with the person's intentions, reasons for coming to the UK, employment record, length and continuity of residence in another country and 'centre of interest' (Bolderson and Roberts, 1994; Roberts, 1997; Roberts, 2000b).

\section{Prior Period of Residence}

A number of countries require a prior period of residence as a condition for the receipt of some non-contributory benefits. For example, in Finland, in order to be eligible for Invalidity benefit it is necessary to have lived in the country for a total of five years. Here Finland discriminates directly between Finnish nationals and third country nationals in that a Finnish national only has to have been resident in Finland for three years after the age of 16.

In Luxembourg, in order to qualify for the general social assistance benefit, the Revenue Minimum Garanti and two categorical benefits, Severe Disability Allowance and Heating Allowance, it is necessary to be a legal resident for ten of the past twenty years; while the Care Allowance requires residence for ten of the past fifteen years.

The non-contributory benefits in Spain - Non-Contributory Retirement Pension, Invalidity Benefit, Unemployment Assistance and the locally administered Ingreso Minimo de Insercion - all have residence conditions attached to them. It is necessary to have been a resident for ten years since the age of 16 for the Non-Contributory Retirement Pension, five years for the Non-Contributory Invalidity Benefit and to have three to five years' local residence for the Ingreso Minimo de Insercion. 
Each of the member countries accords different immigration statuses to newcomers, with asylum seekers and those granted exceptional leave to remain the least secure at the bottom rung of the 'ladder' and those who have been naturalised the most established at the top. The ease with which immigrants may move up the ladder to acquire settlement and/or nationality varies from country to country (Roberts, 1998a).

The interface between the immigration rules and the benefit regulations means that entitlement to benefit at the different stages of settlement varies from country to country. Asylum seekers fall, in part, outside the main social security arrangements. The social security entitlements of asylum seekers not only vary considerably from country to country but also within the same country. Some countries house a proportion of asylum seekers in reception centres while the remainder must enter the housing market. In other countries there are no co-ordinated reception policies

The provision made for those staying in reception centres where they exist may include free food, clothing and accommodation. In some countries, additional one-off payments may be made on arrival to take account of immediate special needs of asylum seekers. Those staying outside reception centres may either receive a cash allowance paid at a rate equivalent to national benefits or more often an amount paid at a rate lower than the rate paid to nationals. In some countries the assistance is payable for a limited period only. In a few countries there is no obligation on the state to provide either social assistance or accommodation. As a consequence, asylum seekers awaiting the result of their application must rely on charity or sleep rough on the streets.

Some countries allow asylum seekers to work, while others deny them access to the labour market. In those countries where asylum seekers are allowed to work they may pay contributions and theoretically gain entitlement to social security benefits. However, in practice the lead times for even short-term benefits make it very unlikely that they will accrue enough contributions to gain entitlement.

Shorter-term residents are not debarred from contributory benefits, the largest group of which in each country are pensions. However, such benefits are not in reality of much use to the shorter-term residents because of their long lead times, unless such residents can aggregate any contributions made, or time served, in the old country with such periods in the new, or transfer any accruements from the second country to a third. Failing these arrangements, short-term residents may need to fall back on various forms of social assistance or means -tested alternatives in the receiving country which are in most countries often localised and discretionary, carrying least clear entitlements, and in many cases not available to shorter-term residents (Roberts and Bolderson, unpublished, 1993).

In some countries those who have attained permanent residence status or its equivalent are eligible for all benefits. In others, migrants with established long- term residence status are, as the result of benefit entitlement conditions that restrict benefit to nationals only, not entitled to any non-contributory benefits. In two countries the long residence requirements attached to the conditions of entitlement to the benefit mean that someone with as long as a five-year residence permit does not qualify for any non-contributory benefit, and that even 
with a special ten-year residence permit may not be entitled to a non-contributory retirement pension.

\section{$5 \quad$ International Social Security Agreements}

The traditional way of overcoming some of the disadvantages experienced by migrants is through international agreements. The history of international social security treaties goes back to the beginning of the twentieth century, although international treaties affecting the rights of aliens have a much longer history (Holloway, 1981; Dummett, 1986; International Labour Organisation, 1992; Nagel and Thalamy, 1994).

Each of the member countries has signed a plethora of international social security agreements. However, large numbers of people in the world are actually or potentially not protected by an international social security agreement should they choose to migrate to an EU member country (Roberts, 1998a ).

Countries that do not have a bilateral agreement with any EU member country are mainly, but not exclusively, developing countries. Intuitively one might expect that the countries without an agreement would be those between which migration flows have been historically non-existent or small. If this were the case there would either be no need for an agreement, or the administrative costs of negotiating and maintaining a bilateral agreement might outweigh the gain of a relatively small number of its own migrants.

However a number of countries with large stocks of migrants in an EU country do not have a bilateral agreement. Apart from an agreement between France and Senegal, there are no agreements with sub-Saharan Africa. Yet Belgium, France and the UK all had longstanding African empires, and each has a long history of migration flows from their former African colonies. There are over 12,000 Zaireians in Belgium, and 90, 000 West Africans and 47,000 East Africans in the UK. These figures include people from Nigeria, Ghana, the Sudan, Uganda and Kenya. In addition to migrants from these ex-colonial countries there are nearly 35,000 Senegalese, 19,000 Somalians, 14,000 Ethiopians and 14,000 Ghanaians in Italy; and 9,000 Ethiopians in Sweden (SOPEMI, 1999).

There is only one agreement with the Indian subcontinent, that between Denmark and Pakistan, despite there being 139,000 Indians, 69,000 Pakistanis and 69,000 Bangladeshis in the UK, over 14,000 Indians in Spain, over 28,000 Sri Lankans in Italy, and over 5,000 Sri Lankans in Denmark (SOPEMI, 1999).

Apart from the agreements between the Philippines and Italy and the Philippines and Spain, there are no agreements with any other Asian countries. This is despite significant populations of Vietnamese in Denmark, Finland, France and Sweden, Thais in Denmark, Chinese in Finland, Italy and Spain, Cambodians and Loatians in France, and Filipinos in Denmark.

There are significant ex-colonial populations, which have been present for several decades where there is no agreement. There are no agreements between Belgium and 
Zaire, France and Cambodia, Laos or Vietnam, Italy and Ethiopia, Spain and the Dominican Republic, Colombia or Cuba, or the UK and India, Pakistan, Bangladesh, all but two of the Caribbean countries, or any country in East or West Africa.

The explanation for the lack of bilateral agreements with so many developing countries, which have large migrant populations in the EU, can be found in the principle of reciprocity that lies at the heart of bilateral social security agreements. Reciprocity is not a precise concept but one born out of negotiation between the countries concerned (Tamango, 1993). However, the important theoretical characteristic of the principle is that each party shares the costs and benefits on a reasonably equal basis.

Where bilateral agreements do exist, the protection provided is variable. Bilateral agreements are extremely heterogeneous despite model agreements having been produced by international bodies such as the ILO and the Council of Europe or by the individual countries themselves (Bolderson and Gains, 1993; International Labour Organisation, 1996a, 1996b, 1996c; Council of Europe, 1995).

\section{A Hierarchy of Statuses}

Whether or not third country nationals are covered by social security therefore depends on their immigration status as determined by immigration policies, on the type of benefits in question and the entitlement conditions governing them and on whether the countries between which they are travelling are covered by international agreements. This is further complicated by some third country nationals having rights under Association and Cooperation Agreements and Council of Europe Instruments and whether the interpretation given both by national courts and the ECJ to those agreements which form part of EU law are favourable (Roberts, 1998b). All this adds up to a jumble of different statuses and entitlements. This jumble means that a third country national may be treated entirely differently under the same circumstances from one member country to another, or two migrants from different third countries may be treated entirely differently in the same member state. Like cases may be treated entirely differently on the sole criterion of the person's country of origin (Roberts, 1998a, 2000a). It is quite possible that the same person could move in and out of social security protection by moving between member countries, or by getting married or divorced (Guild, 1992).

\section{$7 \quad$ Beyond Reciprocity}

The EU member countries have sought to give coherence to the social security arrangements made for EU nationals via Regulation 1408/71. The original aim of Regulation 1408/71 was to facilitate the free movement of workers within the Community. Free movement and the regulations that co-ordinate social security for migrants within the Community are reserved for nationals of a member country. Third country nationals do not enjoy the right of free movement and are not covered by the co-ordinating regulations with the exception of derived rights for family members of EU nationals who exercise their right of free movement. Regulation 1612/68, which forbids discrimination based on nationality in entitlement to social assistance for migrant workers, is similarly confined to EU nationals. 
The European Commission has argued that the diversity of social security rights for third country nationals calls for a coherent approach co-ordinated across the EU by the Commission (European Commission, 1993). There are currently two parallel proposals from the European Commission to extend the personal scope of Regulation 1408/71 to include third country nationals (Verschueren, 1998; Roberts, 2000). One is a freestanding proposal to amend Article 2 of the Regulation so that it is not confined to nationals of the member countries only (OJ C6 of 10.1.98). The other is incorporated to the same effect into the proposal to simplify the co-ordination of social security for migrant workers, itself part of the second phase of the (SLIM) (Simpler Legislation for the Single Market) exercise (OJ C38 of 12/2/99).

The recent history of the proposal can be traced back to the Green Paper of 1993 timed to coincide with the ratification of the Maastricht Treaty. In the Green Paper the Commission argued that 'Immigration calls for realistic, coherent, and complex arrangements based on fundamental principles the equality of rights and obligations is an essential condition for achieving solidarity between the various elements of society' (European Commission, 1993, p 48).

Inter alia the Commission argued that the question should be addressed whether it is still justified to exclude third country nationals, simply because of their nationality, from the protection offered by the co-ordination of social security schemes under Regulation 1408/71 (European Commission, 1993).

Although Regulation 1408/71 co-ordinates social security for migrant workers moving around the Community, the effect of an extension to include third country nationals would be more dramatic as it would harmonise some conditions of entitlement for such people throughout the EU whether or not they had moved between member countries.

Regulation 1408/71 covers contributory, and special non-contributory benefits but not social assistance. The proposed extension of the regulation will thus root out any nationality conditions presently attached to special non-contributory benefits but will leave untouched any such conditions attached to social assistance. However, it is assistance benefits that are most often restricted to nationals and it is these benefits that migrants may most need, either because they have been unable to build up sufficient contributions for a full long-term benefit, or because their entitlement to a short-term insurance benefit has expired; or if they are asylum seekers or family members, because they have no attachment to the labour market.

The Commission's proposal is thus only a partial solution to the disentitlements faced by third country nationals in the member countries of the EU. Nevertheless, it may be seen, not only as the beginning of a rationalisation of social security for third country nationals, but also as an important step beyond the principle of reciprocity towards a more inclusive concept of European citizenship. 


\section{References}

Bolderson, H. and Gains, F. (1993) Crossing National Frontiers: An Examination of the Arrangements for Exporting Social Security Benefits in Twelve OECD Countries.

London: HMSO.

Bolderson, H. and Roberts, S. (1994) 'New Restrictions on Benefits for Migrants:

Xenophobia or Trivial Pursuit?’, Benefits, December.

Bolderson, H. and Roberts, S. (1997) 'Social Security Across National Frontiers' in Social Security and Population Movement.' Journal of International and Comparative Welfare: Special edition 'New Global Development', Vol. XIII, 1997.

Castles, S. and Miller, M. (1993) The Age of Migration. London: Macmillan.

Clout, H., Blacksell, M., King, R. and Pinder, D. (eds.) (1989) Western Europe:

Geographical Perspectives. Harlow. Longman.

Council of Europe (1995a) Model Provisions for a Bilateral Social Security Agreement and Explanatory Report, Strasbourg: Council of Europe.

Dummett, A. (ed.) (1986) Towards a Just Immigration Policy. London: Cobden Trust.

European Commission (1993) European Social Policy: Options for the Union. Green Paper Com (93) 551. Brussels: DG V.

European Commission (1995) Social Security in Europe: Equality between Nationals and Non-Nationals. Lisbon: Departamento de Relacoes Internacionais e Convencoes de Seguranca Social.

Guild, E. (1992) Protecting Migrants' Rights: Application of EC Agreements with Third Countries. Brussels: Churches Committee for Migrants in Europe.

Holloway, J. (1981) Social Policy Harmonisation in the European Community. Farnborough: Gower.

International Labour Organisation (1992) Repertoire Des Instruments Internationaux de Securite Sociale. Geneve: Bureau International du Travail.

International Labour Organisation (1996a) International Labour Conventions and Recommendations 1919-1951. Geneva: International Labour Office.

International Labour Organisation (1996b) International Labour Conventions and Recommendations 1952-1976. Geneva: International Labour Office.

International Labour Organisation (1996c) International Labour Conventions and

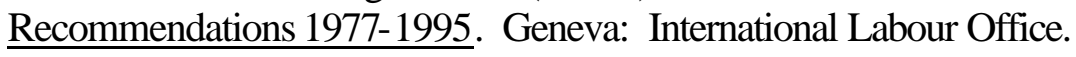


Jorens, Y. (1997) De rechtspositie van niet-EU-onderdanen in het Europese socialezekerheidsrecht. Die Keure: Brugge.

King, R. 'The Social and Economic Geography of Labour Migration: From Guestworkers to Immigrants' in Pinder, D. (1990) (ed.) Western Europe: Challenge and Change.

London: Belhaven.

Nagel, S. and Thalamy, C. (1994) Le Droit international de la securite sociale. Paris:

Paris, Presses Universitaires de France.

OJ C6 of 10.1.98 (Official Journal of the European Communities).

OJ C38 of 12/2/99 (Official Journal of the European Communities).

Roberts, S. and Bolderson, H. (unpublished 1993) 'How closed are Welfare States?' Migration, Social Security and National Frontiers: Social Security Provisions for Non-EU Nationals in Six EU Countries. Paper given to the Annual Conference of the International Sociological Association, Oxford, September.

Roberts, S. (1995) 'Nationality and Equal Treatment: Access to Social Security Benefits and the National Health Service for Non-EEA Nationals under British Law' in von Maydell, B. and Schulte, B. Treatment of Third-Country Nationals in the EU and EEA Member States in Terms of Social Security Law. Max Planck Institut fur Auslandisches und Internationales Socialrecht, Munich, in collaboration with the Commission for the European Communities. Leuven: Peeters.

Roberts, S. (1997) 'Anspruchsvoraussetzungen fur Leistungen der Sozialen Sicherheit, des Sozialen Schutzes und der Gesundheitsversorgung fur Drittstaatsangehorige in Grosbritannien' in Barwig, K., Sieveking, K., Brinkmann, G., Lorcher, K. and Roseler, S. (eds.) Sozialer Schutz von Auslandern in Deutschland. Baden-Baden: Nomos Verlagsgesellschaft.

Roberts, S. (1998a) Not One of Us: Social Security for Third Country Nationals in the European Union. $\mathrm{PhD}$ thesis, Brunel University.

Roberts, S. (1998b) 'The rulings of the European Court of Justice on the Association and Co-operation Agreements in matters concerning social security' in. Ed. Jorens, Y. and Schulte, B., Die Keure la Charte (1998) European Social Security Law and Third Country Nationals Brussels.

Roberts, S., and Bolderson, H. (1999) 'Inside Out: A Cross-National Study of Migrants' Disentitlements to Social Security Benefits', in Ed. J. Clasen, Comparative Social Policy. Oxford: Blackwell.

Roberts, S. (2000a) 'Our view has not changed'. The UK's response to the proposal to extend co-ordination of social security to third country nationals. European Journal of Social Security, Vol II, issue 2. 
Roberts, S. (2000b, forthcoming) 'A Strong and Legitimate Link.' The Habitual Residence Test in the UK. Paper originally presented at the conference in Helsinki 'From Citizenship to Residence. Access to Social Protection in the Nordic and EU Countries' 10-11 March 2000, Helsinki.

Rokkan, S. and Urwin, D. (1983) Economy, Territory, and Identity. London: Sage.

SOPEMI (1992) Trends in International Migration. Paris: OECD.

Tamango, E. (1994) Coordination of Social Security Programmes of Developed and Developing Countries. ISSA, Geneva.

Thomas, E. J. (ed.) (1982) Immigrant Workers in Europe: Their Legal Status. Paris, UNESCO.

Verschueren, H. (1998) 'The Commission's proposal to extend Regulation (EEC) No 1408/71 to Third Country Nationals' in Jorens Y and Schulte, B. (eds.) European Social Security Law and Third Country Nationals. Antwerp: Max-Planck Institut fur Auslandisches und Internationales Sozial Recht/ die keure.

von Maydell, B. (1995) 'Treatment of Third-Country Nationals in the Member States of the European Union and the European Economic Area in Terms of Social Law' in Commission for the European Communities (1995) Social Security in Europe: Equality between Nationals and Non-Nationals. Lisbon: Departamento de Relacoes Internacionais e Convencoes de Seguranca Social.

von Maydell, B. and Schulte, B (1995) Treatment of Third-Country Nationals in the EU and EEA Member States in terms of Social Security Law, Max Planck Institut for Auslandisches und Internationales Socialrecht, Munich, in collaboration with the Commission for the European Communities. Leuven: Peeters. 